\title{
Optical Investigation of GaNAs
}

B.M. Keyes, J.F. Geisz, P.C. Dippo, R. Reedy,

C. Kramer, D.J. Friedman, S.R. Kurtz, and J.M. Olson

National Renewable Energy Laboratory

Presented at the National Center for

Photovoltaics Program Review Meeting

Denver, Colorado

September 8-11, 1998

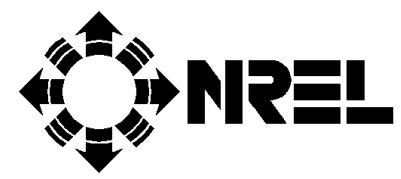

National Renewable Energy Laboratory 1617 Cole Boulevard Golden, Colorado 80401-3393

A national laboratory of the U.S. Department of Energy Managed by Midwest Research Institute for the U.S. Department of Energy under contract No. DE-AC36-83CH10093

Work performed under task number PV803101

October 1998 


\begin{abstract}
NOTICE
This report was prepared as an account of work sponsored by an agency of the United States government. Neither the United States government nor any agency thereof, nor any of their employees, makes any warranty, express or implied, or assumes any legal liability or responsibility for the accuracy, completeness, or usefulness of any information, apparatus, product, or process disclosed, or represents that its use would not infringe privately owned rights. Reference herein to any specific commercial product, process, or service by trade name, trademark, manufacturer, or otherwise does not necessarily constitute or imply its endorsement, recommendation, or favoring by the United States government or any agency thereof. The views and opinions of authors expressed herein do not necessarily state or reflect those of the United States government or any agency thereof.
\end{abstract}

Available to DOE and DOE contractors from:

Office of Scientific and Technical Information (OSTI)

P.O. Box 62

Oak Ridge, TN 37831

Prices available by calling 423-576-8401

Available to the public from:

National Technical Information Service (NTIS)

U.S. Department of Commerce

5285 Port Royal Road

Springfield, VA 22161

703-605-6000 or 800-553-6847

or

DOE Information Bridge

http://www.doe.gov/bridge/home.html 


\title{
Optical Investigation of GaNAs
}

\author{
B.M. Keyes, J.F. Geisz, P.C. Dippo, R. Reedy, C. Kramer, \\ D.J. Friedman, Sarah R. Kurtz, and J.M. Olson \\ National Renewable Energy Laboratory \\ 1617 Cole Blvd., Golden, CO 80401
}

\begin{abstract}
A systematic study of the energy and time-resolved photolumienscence of $\mathrm{GaInP} / \mathrm{GaN}_{\mathrm{x}} \mathrm{As}_{1-\mathrm{x}}$ double heterostructures has been performed for $0 \mathrm{x} 1.3 \%$. A large temperature-dependent optical-bowing coefficient (about 20-25 eV) is observed and the bandgap variation with temperature is found to depend on the nitrogen content. Finally, the minoritycarrier lifetime is not simply related to the nitrogen content. Instead, the recombination rate is proportional to the majority-carrier concentration for $\mathrm{x} \quad 0.3 \%$ and the carbon concentration for $\mathrm{x} \quad 0.3 \%$.
\end{abstract}

\section{INTRODUCTION}

Epitaxial GaAs, when alloyed with nitrogen, exhibits a reduction in the bandgap and lattice constant $(1,2)$. The bandgap reduction is surprising because $\mathrm{GaN}$ has a much larger bandgap than GaAs $(3.4 \mathrm{eV}$ vs. $1.4 \mathrm{eV}$ at room temperature, respectively). Furthermore, these variations may be large enough to allow the $\mathrm{GaN}_{\mathrm{x}} \mathrm{As}_{1-\mathrm{x}}$ ternary to achieve, under different values of $\mathrm{x}$, a bandgap of interest to the telecommunications industry $(1.3 \mu \mathrm{m})$ as well as lattice constant equivalent to that of Silicon.

Of interest to the PV Program, this ternary can further be alloyed with indium to provide a 1-eV direct-gap $\mathrm{Ga}_{0.92} \mathrm{In}_{0.08} \mathrm{~N}_{0.03} \mathrm{As}_{0.97}$ quaternary that is lattice-matched to GaAs. Incorporation of this material as a third junction under the currently successful GaInP/GaAs tandem cell has the potential to increase the calculated idealized AM1.5D conversion efficiency (at 500 suns) to more than $46 \%$, and more than $50 \%$ with the incorporation of a junction in an underlying Ge substrate(3).

GaInNAs material grown to date exhibit very low diffusion lengths(4), a significant problem for application as a photovoltaic material. This study focuses on the optical and material qualities of $\mathrm{GaN}_{\mathrm{x}} \mathrm{As}_{1-\mathrm{x}}$ with $\mathrm{x} \quad 1.3 \%$, which is where much of this degradation occurs.

\section{EXPERIMENTAL PROCEDURE}

A series of $\mathrm{GaN}_{\mathrm{x}} \mathrm{As}_{1-\mathrm{x}}$ films were grown by atmospheric pressure metal organic vapor phase epitaxy (MOVPE) using trimethythylgallium, arsine, and dimethylhydrazine (DMHy) sources. The pressure reactor is a standard vertical tube reactor utilizing radio-frequency $(\mathrm{RF})$ heating. The growth temperature was $650 \mathrm{C}$, 
and the growth rate about $7 \mu \mathrm{m} /$ hour. The nitrogen content was varied from $\mathrm{x}=0$ to 0.013 by varying the DMHy-to-total-group-V ratio. All films were grown on GaAs substrates.

The device structures were 1- $\mu$ m-thick $\mathrm{GaN}_{\mathrm{x}} \mathrm{As}_{1-\mathrm{x}}$ double heterostructures (DH) with 0.1- $\mu \mathrm{m}$-thick GaInP passivating layers. All DHs were doped n-type, using $\mathrm{Si}$, with electron carrier concentrations ranging from $10^{16}$ to $10^{18} \mathrm{~cm}^{-3}$. The majoritycarrier concentrations were determined from capacitance-voltage measurements performed in an electrochemical cell from Bio-Rad.

The nitrogen content of the $\mathrm{GaN}_{\mathrm{x}} \mathrm{As}_{1-\mathrm{x}}$ films was determined from (004) reflection double-crystal $\mathrm{x}$-ray diffraction (XRD) and secondary ion mass spectroscopy (SIMS) measurements. On samples where both measurements were performed, the XRD analysis was in agreement with the SIMS data provided the $\mathrm{GaN}_{\mathrm{X}} \mathrm{As}_{1-\mathrm{x}}$ layers were assumed to be coherently strained. From the XRD data, the lattice mismatch $(\Delta \mathrm{a} / \mathrm{a})$ was found to be $0.3 \%$ for the $\mathrm{x}=0.013$ sample. For comparison, $\Delta \mathrm{a} / \mathrm{a}=0.16 \%$ for AlAs on GaAs.

The optical characterization was performed by spectrally and temporally resolved photoluminescence measurements. The bandgaps were determined as a function of nitrogen concentration and sample temperature $(10 \mathrm{~K} \quad \mathrm{~T} \quad 300 \mathrm{~K})$ using photoluminescence (PL) spectroscopy. The excitation source was a HeNe laser (632.8 $\mathrm{nm} ; 18 \mathrm{~mW} ; 250-\mu \mathrm{m}$ spot size) and the PL was detected by a silicon charge-coupled device (CCD) array. The lifetimes were determined by the single-photon counting technique, also known as time-resolved photoluminescence (TRPL). The excitation source was a cavity-dumped dye laser $(600 \mathrm{~nm} ; 1-10 \mathrm{~mW} ; 0.5-1-\mathrm{mm}$ spot size $)$, and the signal was detected by a micro-channel plate (MCP) photomultiplier detector.

\section{RESULTS AND DISCUSSION}

\section{Photoluminescence of GaNAs}

Figures 1 and 2 show the steady-state photoluminescence spectra at $10 \mathrm{~K}$ and $300 \mathrm{~K}$, respectively, as a function of the nitrogen content. Evident in these spectra is the strong redshift associated with the addition of nitrogen. There is also a corresponding increase in the FWHM between the GaAs and $\mathrm{GaN}_{0.013} \mathrm{As}_{0.987}$ sample, from 31 to $33 \mathrm{meV}$ at $10 \mathrm{~K}$ and from 68 to $85 \mathrm{meV}$ at $300 \mathrm{~K}$. Figure 3 shows the PL peak energy as a function of nitrogen content for both temperatures. Assuming a linear relationship between this energy and the nitrogen content, $\mathrm{x}$, results in a slope of -26 and $-21 \mathrm{eV}$ over the linear region ( $\mathrm{x} 1 \%$ ) for the $10 \mathrm{~K}$ and $300 \mathrm{~K}$ data, respectively.

The dependence of the bandgap, $\mathrm{E}_{\mathrm{g}}$, on the nitrogen composition can be analyzed using a mixed-alloy type of relationship

$$
\mathrm{E}_{\mathrm{g}}(\mathrm{x})=\mathrm{xE}_{\mathrm{g}}(\mathrm{GaN})+(1-\mathrm{x}) \mathrm{E}_{\mathrm{g}}(\mathrm{GaAs})-\mathrm{bx}(1-\mathrm{x}),
$$




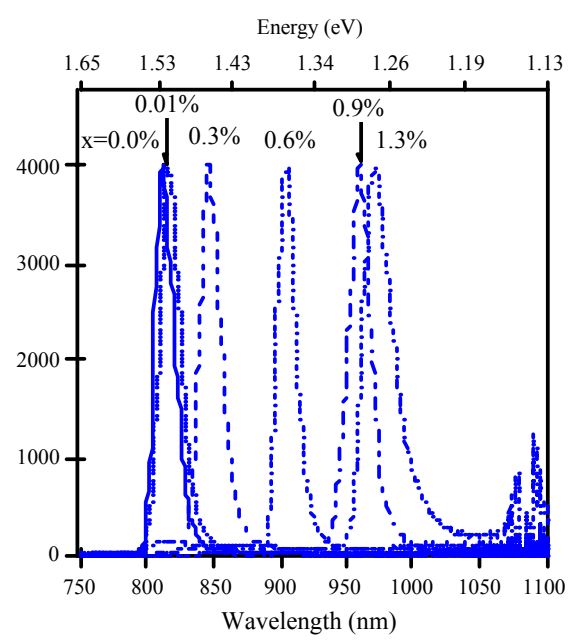

FIGURE 1. $\mathrm{GaN}_{\mathrm{x}} \mathrm{As}_{1-\mathrm{x}}$ photoluminescence spectra at $10 \mathrm{~K}$.

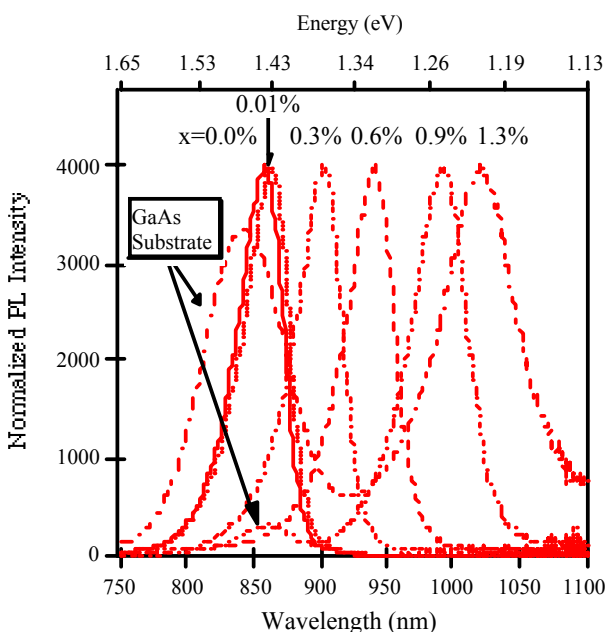

FIGURE 2. $\mathrm{GaN}_{\mathrm{x}} \mathrm{As}_{1-\mathrm{x}}$ photoluminescence spectra at $300 \mathrm{~K}$.

where $\mathrm{E}_{\mathrm{g}}(\mathrm{GaN})$ is 3.5 and $3.4 \mathrm{eV}$ for 10 and $300 \mathrm{~K}$, respectively. Fitting of this expression to the PL peak energy, which will track with the bandgap energy, results in linear appearing fits with an optical-bowing coefficient, b, equal to 24 and $21 \mathrm{eV}$ for the $10 \mathrm{~K}$ and $300 \mathrm{~K}$ data, respectively. Solving for $\mathrm{b}$ on a point-by-point basis from the change in PL peak energy with respect to the unalloyed GaAs peak results in the $b$ values listed in Table 1.

The particularly strong dependence of the bandgap on nitrogen content is in agreement with other experimental $(1,2)$ and theoretical $(5)$ work. The $x=0.009 \%$ sample, where there is a real redshift in the PL spectra and b approaches $100 \mathrm{eV}$, is anomalous and may be due to transitions involving a shallow N-related impurity band. For comparison, the $\mathrm{b}$ value for the AlGaAs system is $1 \mathrm{eV}$.

The temperature dependence of the PL Peak is shown in Figure 4 and is analyzed using the expression by O'Donnell and Chen(6)

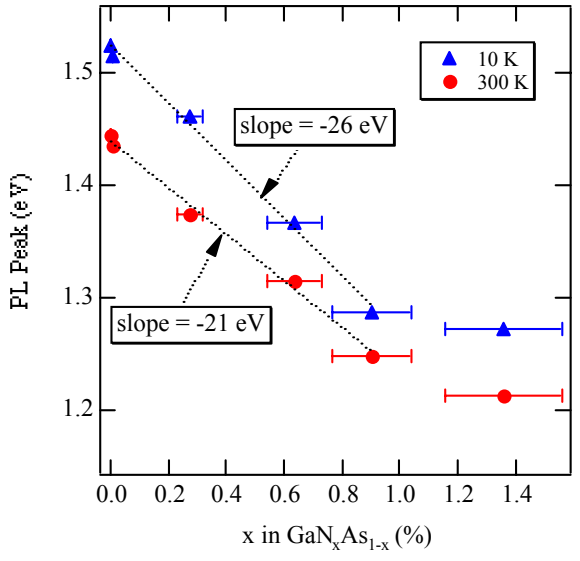

FIGURE 3. PL peak energy of $\mathrm{GaN}_{\mathrm{x}} \mathrm{As}_{1-\mathrm{x}}$ as a function of the nitrogen concentration.
TABLE 1. Optical bowing coefficient from the data of Figure 3 and Equation 1.

\begin{tabular}{lll}
\hline $\mathrm{x}(\%)$ & $\mathrm{b} @ 10 \mathrm{~K}$ & $\mathrm{~b} @ 300 \mathrm{~K}$ \\
\hline 0.009 & $95( \pm 50) \mathrm{eV}$ & $95( \pm 50) \mathrm{eV}$ \\
0.3 & $25( \pm 5)$ & $28( \pm 5)$ \\
0.6 & 27 & 16 \\
0.9 & 28 & 24 \\
1.3 & 21 & 19
\end{tabular}




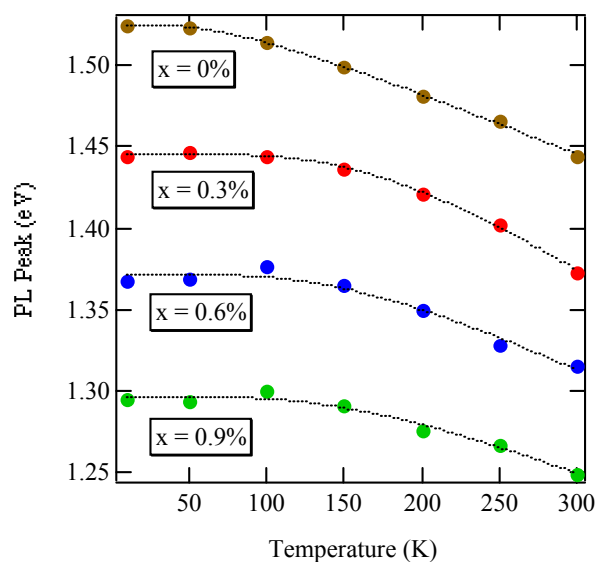

TABLE 2. $\mathrm{E}_{\mathrm{g}}(\mathrm{T})$ fitting parameters for the fits in Figure 4 using Equation 2.

\begin{tabular}{llll}
\hline $\mathrm{x}(\%)$ & $\mathrm{E}_{\mathrm{g}}(0)$ & $\mathrm{S}$ & $\langle\hbar \omega\rangle$ \\
\hline 0 & $1.52 \mathrm{eV}$ & $2.3( \pm 0.3)$ & $19( \pm 6) \mathrm{meV}$ \\
0.3 & 1.45 & $4.7( \pm 1.4)$ & $53( \pm 10)$ \\
0.6 & 1.37 & $3.1( \pm 1)$ & $45( \pm 10)$ \\
0.9 & 1.29 & $2.6( \pm 1)$ & $46( \pm 10)$
\end{tabular}

FIGURE 4. PL peak energy of $\mathrm{GaN}_{\mathrm{x}} \mathrm{As}_{1-\mathrm{x}}$ as a function of the temperature.

$$
\left.E_{g}(T)=E_{g}(0)-S\langle\hbar \omega\rangle\left[\operatorname{coth}\left(\{\hbar \omega\rangle / 2 k_{B} T\right)-1\right)\right],
$$

where $\mathrm{S}$ is a coupling constant $(7)$ and $\langle\hbar \omega\rangle$ is an average phonon energy. The results of the fits are compiled in Table 2. From these data, it can be seen that the temperature dependence of the bandgap energy changes when going from GaAs to $\mathrm{GaN}_{\mathrm{x}} \mathrm{As}_{1-\mathrm{x}}$. This is most evident in the $\langle\hbar \omega\rangle$ fitting parameter. This may correspond to the presence of GaN-like modes (the observed Ga-N local vibrational mode is 58 meV)(8) playing a large role in the electron-phonon component of the change in bandgap over this temperature region. Also of note is the $10 \mathrm{meV}$ blueshift that occurs for the $\mathrm{x}=0.6 \%$ and $0.9 \%$ samples between 50 and $100 \mathrm{~K}$. This may be due to a presence of ordering effects in this ternary(9) and suggests that improved characterization of the average bandgap may be achieved through various modulation techniques.

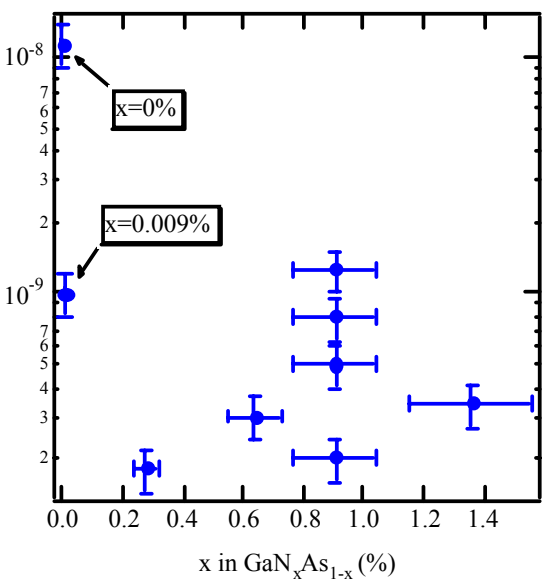

FIGURE 5. Lifetime of $\mathrm{GaN}_{\mathrm{x}} \mathrm{As}_{1-\mathrm{x}}$ as a function of the nitrogen concentration.

\section{Time-Resolved Photoluminescence of GaNAs}

The minority-carrier lifetime, as measured by TRPL, is shown as a function of nitrogen content in Figure 5. While the incorporation of nitrogen in GaAs does result in a reduction in the lifetime $(\tau)$, there is no clear functional dependence between $\tau$ and the relative percentage of nitrogen, $x$. Correspondingly, because the amount of strain is directly related to the nitrogen content, this also implies that lattice mismatch is not the source of the dominant recombination mechanism. In fact, 


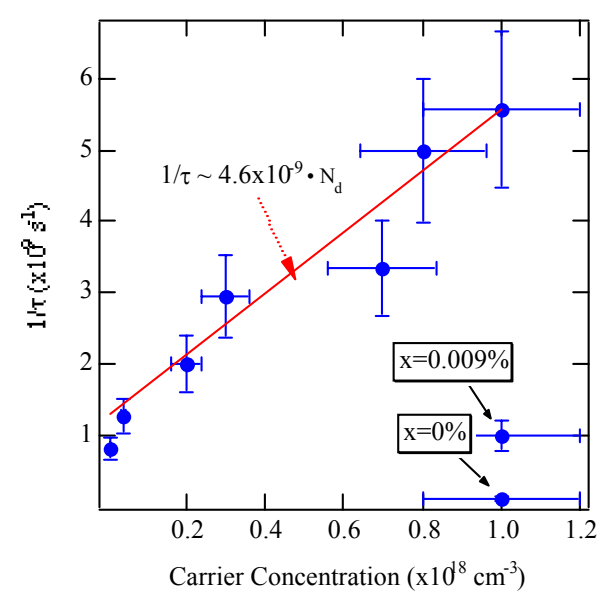

FIGURE 6. Recombination rate of $\mathrm{GaN}_{\mathrm{x}} \mathrm{As}_{1-\mathrm{x}}$ as a function of the majority-electron concentration. comparison of the XRD and SIMS data imply that these films remain coherently strained. Closer analysis of the data does reveal a relationship between $\tau$ and the carrier concentration, $\mathrm{N}_{\mathrm{d}}$.

As can be seen in Figure 6, for $0.3 \% \times 1.3 \%$, the recombination rate, $1 / \tau, \quad$ is proportional to the majorityelectron concentration, independent of the nitrogen content. Specifically,

$$
1 / \tau=1 / \tau_{0}+4.6 \times 10^{-9} \cdot \mathrm{N}_{\mathrm{d}}
$$

where $\tau_{0}=1 \mathrm{~ns}$. Assuming the relevant defect density is equal to $\mathrm{N}_{\mathrm{d}}$, this corresponds to a hole capture cross section, $\sigma_{\mathrm{p}}$, of about $2 \times 10^{-16} \mathrm{~cm}^{-2}$. This type of relationship typically signifies radiative band-to-band transitions as the rate-limiting process. The difficulty with this supposition in this case is that the resulting volume capture rate $\left(4.9 \times 10^{-9} \mathrm{~cm}^{3} / \mathrm{s}\right)$ is not expected to be that different from the GaAs value $\left(2 \times 10^{-10} \mathrm{~cm}^{3} / \mathrm{s}\right)(10,11)$. Thus, these lifetimes are considerably lower than expected for this type of transition.

The lifetime of lowest nitrogen containing DHs do not correlate directly with the carrier concentration. Furthermore, as can be seen in Figure 7, at a constant carrier concentration of $10^{18} \mathrm{~cm}^{-3}$, the recombination rate for $\mathrm{x} \quad 0.3 \%$ is not proportional to the nitrogen concentration. Instead, for $\mathrm{x} \quad 0.3 \%$, the recombination rate is found to be proportional to the carbon concentration (Figure 8). The resulting volume capture rate of $9 \times 10^{-8} \mathrm{~cm}^{3} / \mathrm{s}$, corresponds to a hole capture cross section of about $5 \times 10^{-15} \mathrm{~cm}^{-2}$.

It is possible that there are $\mathrm{Si}-, \mathrm{C}-$, and/or N-related complexes that are creating

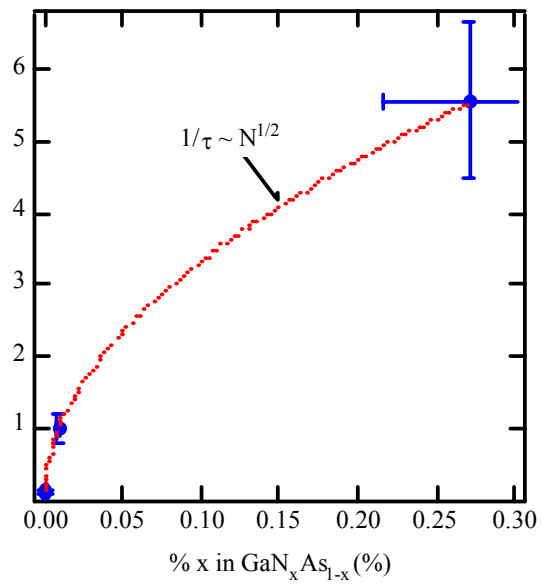

FIGURE 7. Recombination rate of $\mathrm{GaN}_{\mathrm{x}} \mathrm{As}_{1-\mathrm{x}}$ as a function of the nitrogen concentration.

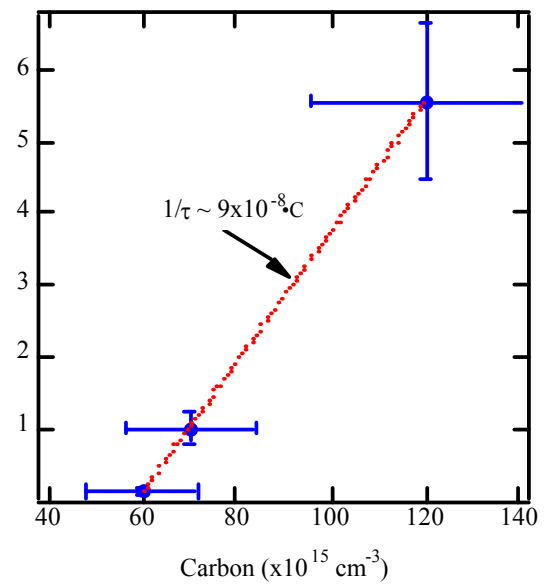

FIGURE 8. Recombination rate of $\mathrm{GaN}_{\mathrm{x}} \mathrm{As}_{1-\mathrm{x}}$ as a function of the carbon concentration. 
the dominant recombination centers. One possibility is a Si-C defect. For example, at low $\mathrm{x}$, and thus low $\mathrm{C}$ concentration, the density of Si-C defects in the highly doped material could be controlled by the $\mathrm{C}$ content. At higher values of $\mathrm{x}$, there may be a sufficiently large $\mathrm{C}$ concentration that the defect density is then controlled by the $\mathrm{Si}$ content. The actual defect density may be some fraction of the total $\mathrm{Si}$ or $\mathrm{C}$ concentration, thus changing the previously calculated $\sigma$ values. In any case, these possibilities need to be investigated further.

\section{CONCLUSION}

From the PL data, the bandgap of $\mathrm{GaN}_{\mathrm{x}} \mathrm{As}_{1-\mathrm{x}}\left(\begin{array}{l}0 \\ \mathrm{x}\end{array} \quad 1.3 \%\right)$ has been tracked as a function of nitrogen concentration. The resulting bowing coefficient is on the order of 20-25 eV. The temperature dependence of the bandgap was also determined over the range $10 \mathrm{~K}$ T $300 \mathrm{~K}$, where there is a quantitative difference between GaAs and the nitrogen-containing compounds.

Finally, the lifetime is not simply related to the nitrogen content. The recombination rate for n-type $\left(10^{18} \mathrm{~cm}^{-3}\right)$ samples with a low Nitrogen concentration ( $\mathrm{x} \quad 0.3 \%$ ) is proportional to the sample's carbon content. The recombination rate for samples with a higher nitrogen concentration $(0.3 \% \quad \mathrm{x} \quad 1.3 \%)$ is proportional to the majority-electron concentration, independent of the nitrogen content.

\section{ACKNOWLEDGEMENTS}

This work was performed under contract No. DE-AC36-83CH10093 with the U.S. Department of Energy.

\section{REFERENCES}

1. Kondow, M., et al., Jpn. J. Appl. Phys., 1994. 33(Part 2, No. 8A): p. L1056-L1058.

2. Weyers, M., M. Sato, and H. Ando, Jpn. J. Appl. Phys., 1992. 31(Part 2, No. 7A): p. L853-L855.

3. Kurtz, S.R., D. Myers, and J.M. Olson. in 26th IEEE Photovoltaic Specialists Conference. 1997. Anaheim, CA.

4. Geisz, J.F., et al., J. Cryst. Growth, 1998. 175.

5. Wei, S.-H. and A. Zunger, Phys. Rev. Lett., 1996. 76(4): p. 664-667.

6. O'Donnell, K.P. and X. Chen, Appl. Phys. Lett., 1991. 58(25): p. 2924-2926.

7. Huang, K. and A. Rhys, Proc. R. Soc. A, 1950. 204: p. 406-423.

8. Alt, H.C., B. Wiedemann, and K. Bethge, Mat. Sci. Forum, 1997. 258-263: p. 867-872.

9. DeLong, M.C., et al., J. Appl. Phys., 1993. 73(10): p. 5163-5172.

10. Casey Jr, H.C. and F. Stern, J. Appl. Phys., 1976. 47(2): p. 631-643.

11. Hall, R.N., Proc. Inst. Elect. Eng., 1960. 106B(Suppl. 17): p. 923-931. 